Microstructure and Properties of Materials 
This page is intentionally left blank 


\title{
Microstructure and Properties of Materials
}

\author{
Editor \\ J.C.M. Li \\ Univ. of Rochester
}




\section{Published by}

World Scientific Publishing Co Pte Ltd

P O Box 128, Farrer Road, Singapore 912805

USA office: Suite 1B, 1060 Main Street, River Edge, NJ 07661

UK office: 57 Shelton Street, Covent Garden, London WC2H 9HE

\section{British Library Cataloguing-in-Publication Data}

A catalogue record for this book is available from the British Library.

\section{MICROSTRUCTURE AND PROPERTIES OF MATERIALS}

Copyright $\odot 1996$ by World Scientific Publishing Co. Pte. Ltd.

All rights reserved. This book, or parts thereof, may not be reproduced in any form or by any means, electronic or mechanical, including photocopying, recording or any information storage and retrieval system now known or to be invented, without written permission from the Publisher.

For photocopying of material in this volume, please pay a copying fee through the Copyright Clearance Center, Inc., 222 Rosewood Drive, Danvers, Massachusetts 01923, USA.

ISBN 981-02-2403-6

Printed in Singapore. 


\section{PREFACE}

This is an advanced text book on the microstructure and properties of materials, the first volume of a possible 3-volume set. While there are many elementary text books in materials science, there are very few advanced text books. In our graduate school courses, we rely on our own notes or some conference volumes and journal articles. One of the reasons is that there are so many different kinds of materials and each has its own microstructure property charateristics. So it is difficult for a single person to be expert in all the materials. Thus the idea of a multi-author collection appears good. I am inviting the best authoritative expert that I can find in each material area and since they are all busy people, it has taken longer than expected to finish the task. Hence this is the first volume which should be a good supplement to your microstructure course. If you are working with a certain material area in one of the chapters, you will find a rich source of design ideas and applications as well as a good understanding of how does the microstructure affect the properties.

Chapter 1 on aluminum alloys presents microstructural optimization and critical considerations in design applications. Chapter 2 on Nickelbase superalloys reviews the compositional, microstructural and processing advances in increasing their maximum use temperature. Chapter 3 on metal matrix composites discusses the strengthening mechanisms of metals dispersed with short fibers or particles. Chapter 4 on polymer matrix composites contains the details of the microstucture property relationships of high performance fibers, polymer matrix material and the advanced composties made therewith. Chapter 5 on ceramics matrix composites describes the fibers and matrix materiais used, the processing techniques involved and the mechanical properties under different loading conditions. Chapter 6 on inorgainic glasses describes the influence of second phases, both glassy and crystalline on their properties. Chapter 7 on superconducting materials shows the importance of twins, grain boundaries, dislocations and stacking faults. Chapter 8 on magnetic materials introduces the domain structure and its effects on the soft and hard magnetic properties.

Material problems are the bottle necks of most industries. New materials are created daily. But the principles and the relation between properties and microstructure remains the same. The more we know about these relations the easier will be to find new materials with desired properties.

James C. M. Li

Rochester, NY

October, 1995 
This page is intentionally left blank 


\section{CONTENTS}

Preface

Chapter 1 Microstructure and Properties of Aluminium Alloys

C. P. Blakenship, Jr, E. A. Starke and E. Hornbogen

Chapter 2 Nickel-Base Superalloys

N. S. Stoloff

Chapter 3 Metal Matrix Composites

R. J. Arsenault

Chapter 4 Polymer Matrix Composites

Jang-Kyo Kim and Yiu-Wing Mai

Chapter 5 Ceramic Matrix Composites

P. G. Karandikar, T. W. Chou and A. Parvizi-Majidi

Chapter 6 Microstructure of Inorganic Glasses

R. H. Doremus

Chapter 7 Microstructure and Properties of Superconducting

Materials

C. S. Pande

Chapter 8 Magnetic Materials

C. D. Graham, Jr

Subject Index

Author Index 